\title{
Performance of Turmeric (Curcuma longa) under Bamboo (Dendrocalamus strictus) based Agroforestry System in Chhattisgarh
}

\author{
Rupesh kumar* and M. N. Naugraiya \\ Department of Forestry, Indira Gandhi Krishi Vishwavidyalaya, Raipur (C G), India \\ *Corresponding author
}

\section{Keywords \\ Turmeric, Bamboo, Agroforestry system, Ranga variety}

Article Info

Accepted:

30 May 2020

Available Online:

10 June 2020

\section{A B S T R A C T}

Bamboo is a fast growing woody grass and give regular income after three years of growth and thus harvesting of mature culms open the space for light and other atmospheric micro climate factors, suitable for shade loving crop like Haldi and zinger incurrent study two varieties of turmeric (Curcuma longa) viz., Roma and Ranga was cultivated as cover crop at $50 \times 50 \mathrm{~cm}(\mathrm{~S}-1) 50 \times 30 \mathrm{~cm}(\mathrm{~S}-2)$ and $40 \times 30 \mathrm{~cm}(\mathrm{~S}-3)$ spacing under Bamboo (Dendrocalamus strictus) plantation $(8 \times 6 \mathrm{~m})$ and in open field i.e. without tree. Where the yield of fresh turmeric was received under Bamboo plantation $\left(161.46 \mathrm{q} \mathrm{ha}^{-1}\right)$ which was $28.5 \%$ less than open field crop. The yield of Ranga was $206.71 \mathrm{q} \mathrm{ha}^{-1}$ than Roma (180.55 $\left.\mathrm{q} \mathrm{h}^{-1}\right)$. In case of spacing highest yield was received $209.44 \mathrm{q} \mathrm{ha}^{-1}$ and lowest at S2 $\left(177.29 \mathrm{q} \mathrm{ha}^{-1}\right)$. The interaction of cropping system $\mathrm{x}$ variety showed highest yield in open field crop for Ranga (245.67 $\mathrm{q} \mathrm{ha}^{-1}$ ) and than Roma (205.92 $\mathrm{q} \mathrm{ha}^{-1)}$ and under Bamboo plantation it dropped to $167.75 \mathrm{q} \mathrm{ha}^{-1}$ for Ranga and $155.18 \mathrm{q} \mathrm{ha}^{-1}$ for Roma. In case of interaction of cropping system $\mathrm{x}$ spacing, the highest yield was received in open field crop $246.31 \mathrm{q} \mathrm{ha}^{-1}$ at followed by 215.67 and $215.40 \mathrm{q} \mathrm{ha}^{-1}$ at S3 and S2 respectively with insignificant variations. Insignificant interaction of variety $\mathrm{x}$ spacing, gave highest yield $221.00 \mathrm{q} \mathrm{ha}^{-1}$ for at $\mathrm{S} 1$ followed by $206.73 \mathrm{q} \mathrm{ha}^{-1}$ at S3 raged afterward at 197.88 to $162.17 \mathrm{q} \mathrm{ha}^{-1}$. In case interaction of cropping system $\mathrm{x}$ variety $\mathrm{x}$ spacing, was found statistically non-significant where the yield was consistently higher for Ranga at all spacing in open field crop of Turmeric i.e. 241.2 to $252.8 \mathrm{q} \mathrm{ha}^{-1}$, whole under Bamboo plantation the yield was ranged 143.6 to $189.2 \mathrm{q} \mathrm{ha}^{-1}$. Performance of variety Roma was recorded less than Ranga variety of Turmeric either in cropping system of at crop spacing. The population of bamboo was 44.92 culm clump $^{-1}$ and harvesting of matured Bamboo produced 7.30, 3.4 and $1.7 \mathrm{~kg}$ per culm of biomass culm branches and leaves respectively.

\section{Introduction}

Agro-forestry is land-use systems involving trees combined with arable crop and animals on same land unit and provide more than one benefits like timbers, food, fodder and fuel to the farmers. However the fast growing MPTS played an important role to meet out the requirement of rural population. The space in tree crop plantation can be utilized by cultivation of cover crop to generate income. Bamboo a perennial, very fast growing woody grass has great potential not only for increasing green cover but also for generating 
fast return to rural community (Naugraiya and Puri, 1997). Turmeric (Curcuma longa) a shade loving rhizomatous crop is suitable to cultivate as cover crop. The present study was conducted to work out the performance of cover crop of turmeric under bamboo plantation as Agroforestry system.

\section{Materials and Methods}

Turmeric crop was cultivated in well prepared field as per recommended package and practices with application FYM@ 10 tan ha ${ }^{-1}$. Rhizome turmeric variety viz; Ranga $\left(\mathrm{V}_{1}\right)$ and Roma (V2) were sown at three spacing viz; $\mathrm{S} 1(50 \times 50 \mathrm{~cm}), \mathrm{S} 2(50 \times 30 \mathrm{~cm})$ and S3 (40 x $30 \mathrm{~cm})$ under bamboo plantation $(8 \times 6 \mathrm{~m})$ and in open field. The recommended dose of NPK i.e. $120 \mathrm{~N}, 80 \mathrm{P} \& 60 \mathrm{~K} \mathrm{~kg} \mathrm{ha}^{-1}$ were given in form of Urea, SSP \& Murate of Potash as basal and split doses The yield rhizomes of turmeric crop were recorded at seed formation stage at 150 DAS.

The harvesting of mature culms in each clump of Bamboo plantation done every year has been thus growth and biomass production was also recorded.

\section{Results and Discussion}

\section{Soil}

The soil of Raipur belongs to four different orders viz., Entisols, Vertisols, Inceptisols and Alfisols. The black clayey soil of experimental field belongs to the order Vertisols and it is locally known as Kanhar. This Kanhar soil are characterized by fine texture, sticky nature, angular blocky structure, low to medium Nitrogen, high Potassium and low to medium Phosphorus with low Organic matter. The soil of experimental area is very rich in organic carbon and other nutrient because of the addition of litter in the soil every year.

\section{Climate}

The Experiment was started in the month of June 2017 and crop was finally harvested up to April 2018. The meteorological data ranges from experiment time in maximum temperature $310 \mathrm{C}$ and minimum temp. 24.75 OC, relative humidity $93.25 \%$, sun shine 3.575 hours and the rainfall $421.8 \mathrm{~mm}$ was recorded in sowing time of seed on September month and the harvesting time temperature and sun shine was increases. Maximum temp. $41.75{ }^{\circ} \mathrm{C}$ and min. temp. 25.05, relative humidity $39.75 \%$, sun shine 9.37 hours recorded in month of April.

\section{Yield of turmeric}

The rhizomes of turmeric were carefully dug out and cleaned by removing dry shoot, leaves, and roots than washed thoroughly in water to remove soil particles. These rhizomes were weighed after few hours air dry to evaporate moisture. The fresh yield of turmeric was recorded $225.79 \mathrm{q} \mathrm{ha}^{-1}$ in open field (CS-1) and $161.46 \mathrm{q} \mathrm{ha}^{-1}$ in AFS (CS-2) with statistically significant differences. The yield of fresh weight of rhizome was recorded $206.71 \mathrm{qha}^{-1}$ in variety Ranga (V-1) and $180.55 \mathrm{qha}^{-1}$ in variety Roma (V-2) respectively. The rhizome yield was recorded highest $209.44 \mathrm{qha}^{-1}$ in S-1 (50 x 50) spacing followed by $194.16 \mathrm{qha}^{-1}$ in S-3 (40 x 30) and lowest177.29 $\mathrm{qha}^{-1} \mathrm{~S}-2(50 \times \mathrm{x} 30)$ spacing respectively. Though the interaction of cropping system $\mathrm{x}$ spacing showed highest yield of $246.31 \mathrm{q} \mathrm{ha}^{-1}$ in CS-1 x S-1 followed by $215.67 \mathrm{q} \mathrm{ha}^{-1}$ and $215.40 \mathrm{q} \mathrm{ha}^{-1}$ in CS-1 x S-3 and CS-1 $x$ S-2 respectively with minimum of $139.18 \mathrm{q} \mathrm{ha}^{-1}$ in CS-2 x S-2 interaction. The interaction of variety $x$ spacing showed maximum yield $221.00 \mathrm{q} \mathrm{ha}^{-1}$ in V-1 x S1 followed by $206.73 \mathrm{q} \mathrm{ha}^{-1}$ in V-1 $\mathrm{x} \mathrm{S}-3$ with minimum $162.17 \mathrm{q} \mathrm{ha}^{-1}$ in $\mathrm{V}-2 \times \mathrm{S}-$ 2 . In case of interaction of cropping system $x$ variety $x$ spacing the highest yield was 
recorded $252.76 \mathrm{q} \mathrm{ha}^{-1}$ in CS-1 $\mathrm{x} \mathrm{V-1} \times \mathrm{S} 1$ followed by $243.05 \mathrm{q} \mathrm{ha}^{-1}$ in CS-1 1 V V-1 x S-3 with minimum $134.77 \mathrm{~cm}$ in CS-2 $x$ V-2 x S-2 with statistically non significant variations (Table 1 and 2).

\section{Bamboo growth and yield}

Growth and biomass production behaviour of bamboo plantation at $8 \times 6 \mathrm{~m}$ in 18 years plantation showed that the population of culm per clump was recorded 44.9 and it increased to 57.0 in a year with share of matured $(24.8 \%)$, young $(50.8 \%)$, dead $(9.9 \%)$ and new culm $(14.3 \%)$.
Diameter of clumps was $4.88 \mathrm{~m}$. Height of culm was $8.98 \mathrm{~m}$ with diameter of $3^{\text {rd }}$ internodes $3.87 \mathrm{~m}$. The harvesting of mature culm produced total $12.39 \mathrm{~kg} /$ culm fresh biomass which was further shared by 7.30 , $3.4 \pm 0.9$ and 1.6 by clean culm, branches and leaves respectively (Table-3).

In case of varieties Ranga (V1) and Roma (V2) of turmeric, the higher yield recorded highest in Ranga (V1) under bamboo based Agroforestry system where bamboo spacing 8 $\mathrm{x} 6 \mathrm{~m}$.

Table.1 Yield of turmeric crop under bamboo based Agroforestry system

\begin{tabular}{|c|c|c|c|c|c|c|c|c|c|}
\hline \multirow[t]{2}{*}{ Crop spacings } & \multicolumn{2}{|c|}{ CS- 1(Open) } & \multicolumn{2}{|c|}{ CS-2 AFS } & \multirow{2}{*}{$\begin{array}{c}\text { Spacing } \\
\text { (cm) }\end{array}$} & \multicolumn{2}{|c|}{$\begin{array}{l}\text { Cropping system } \\
\text { x Spacing }\end{array}$} & \multicolumn{2}{|c|}{ Variety x Spacing } \\
\hline & Ranga(V1) & $\operatorname{Roma}(\mathbf{V} 2)$ & Ranga(V1) & $\operatorname{Roma}(\mathrm{V} 2)$ & & CS-1 & CS-2 & Ranga(V1) & $\operatorname{Roma}(\mathbf{V} 2)$ \\
\hline$S 1(50 \times 50 \mathrm{~cm})$ & 252.76 & 239.87 & 189.24 & 155.89 & 209.44 & 246.31 & 172.57 & 221 & 197.88 \\
\hline $\mathrm{S} 2(50 \times 30 \mathrm{~cm})$ & 241.22 & 189.58 & 143.59 & 134.77 & 177.29 & 215.4 & 139.18 & 192.4 & 162.17 \\
\hline \multirow[t]{3}{*}{$S 3(40 \times 30 \mathrm{~cm})$} & 243.05 & 188.3 & 170.41 & 174.89 & 194.16 & 215.67 & 172.65 & 206.73 & 181.6 \\
\hline & \multicolumn{4}{|c|}{ Interaction Cropping system $x$ Variety } & & \multicolumn{2}{|c|}{ Cropping system } & \multicolumn{2}{|c|}{ Variety } \\
\hline & 245.68 & 205.92 & 167.75 & 155.18 & & 225.79 & 161.47 & 206.71 & 180.55 \\
\hline
\end{tabular}

Table.2 Analysis of variance ratio ANOVAs

\begin{tabular}{|c|c|r|c|c|c|}
\hline Source & df & \multicolumn{1}{|c|}{ Mss } & SEm \pm & SEd \pm & CD(at 5\%) \\
\hline Replication & 3 & 1348.15 & & & \\
\hline Cropping system & 1 & 49659.49 & 11.48 & 16.24 & $\mathbf{3 2 . 4 7}^{*}$ \\
\hline Variety & 1 & 8211.27 & 11.48 & 16.24 & NS \\
\hline Spacing & 2 & 4138.36 & 14.06 & 19.89 & NS \\
\hline Cs x V & 1 & 2218.76 & 16.24 & 22.96 & NS \\
\hline Cs x Sp & 5 & 547.20 & 19.89 & 28.12 & NS \\
\hline V x Sp & 5 & 21.51 & 19.89 & 28.12 & NS \\
\hline Cs x V x Sp & 11 & 321.84 & 28.13 & 39.77 & NS \\
\hline Error & 18 & 3164.63 & & & \\
\hline
\end{tabular}


Table.3 Growth and yield of bamboo during 2017-18

\begin{tabular}{|c|c|c|}
\hline Parameters & Mar-18 & CAI \\
\hline $\begin{array}{l}\text { A. Population of culm } \\
\left.\text { (n clump }^{-1}\right)\end{array}$ & $57.00 \pm 23.50$ & 12.08 \\
\hline Matured & $\begin{array}{c}14.17 \pm 8.73 \\
(24.85 \%)\end{array}$ & 1.34 \\
\hline Young & $\begin{array}{l}29.00 \pm 10.53 \\
(50.88)\end{array}$ & 1.92 \\
\hline Dead & $\begin{array}{l}5.67 \pm 2.81 \\
\quad(9.94)\end{array}$ & 0.67 \\
\hline New & $\begin{array}{l}8.17 \pm 2.79 \\
(14.33 \%)\end{array}$ & 8.17 \\
\hline $\begin{array}{l}\text { B. growth parameters } \\
\text { Clump diameter (m) }\end{array}$ & $4.88 \pm 0.96$ & 0.84 \\
\hline Height of culm (m) & $8.98 \pm 1.44$ & 1.21 \\
\hline $\begin{array}{l}\text { Diameter of culm at } 3^{\text {rd }} \\
\text { internodes }(\mathrm{cm})\end{array}$ & $3.87 \pm 1.16$ & 0.23 \\
\hline C. Yield (kg/culm) & Dry weight & - \\
\hline $\begin{array}{lr}\text { Culm } & \text { f wt } \\
& \text { d wt }\end{array}$ & $\begin{array}{l}7.30 \pm 0.79 \\
\quad(3.94)\end{array}$ & - \\
\hline Branch & $\begin{array}{l}3.44 \pm 0.91 \\
\quad(0.97)\end{array}$ & - \\
\hline Leaves & $\begin{array}{l}1.66 \pm 0.31 \\
(0.09)\end{array}$ & - \\
\hline $\begin{array}{l}\text { Total weight } \\
\qquad \begin{array}{l}\text { f wt } \\
\text { d wt }\end{array}\end{array}$ & $\begin{array}{l}12.39 \pm 2.66 \\
(5.00 \pm 2.02)\end{array}$ & - \\
\hline
\end{tabular}

Overall the Ranga variety of turmeric found better for cultivation under Agroforestry system as it gave better yield under bamboo based Agroforestry system, similarly crop spacing S-1 (252.89 $\left.\mathrm{qha}^{-1}\right)$ followed by S-2 $\left(241.39 \mathrm{qha}^{-1}\right)$. The yield of turmeric variety Ranga was found better in open it their spacing but it was good enough at spacing 50 x $50 \mathrm{~cm}(\mathrm{~S}-1)$ under bamboo based AFS $\left(189.2 \mathrm{qha}^{-1}\right)$

Agroforestry system was studied by Dindekar (2012) while wheat crop, Harne (2013) with rice crop, jeven (2019) with ginger and reported more or less similar results and they found the $\mathrm{g} / \mathrm{ha}$ clums which was approximately $5.03 \mathrm{~kg} /$ clums.

Bamboo required extensive management as plantations (Chandrashekara, 1996) in agroforestry and hedgerows on farm boundaries etc., (Divakara et al., 2001; Kummar, 1997). The dense crown of clump increases the competition for more sunlight and for resource utilization, thus the harvesting of mature culms from clumps open the space at 
ground and canopy level. Performance of Dendrocalamus strictus under Agroforestry system was studied by Dindekar (2012) while wheat crop, Harne (2013) with rice crop, jewan (2019) with ginger they reported more or less similar results and enhance total yield income as compare to open field solo farming of crops. The cultivation of bamboo on farmlands generated regular yearly income after 3-4 years of plantation (Naugraiya and Puri 1997).

\section{Acknowledgement}

Authors are thankful to head department of forestry, for enhancing the facilities to conduct the research study under M.Sc. (Forestry) thesis program.

\section{References}

Bisht J. K, Chandra, V. S. and Singh R D. (2000). Performance of ginger (Zingiber officinale) and turmeric (Curcuma longa) with fodder tree based silvi-horti system in hills. Indian Journal of Agricultural Sciences. 70(7): 431-433

Chandrashekara, U.M. (1996) Ecology of Bambusa arundinacea (Retz.) Willd. growing in teak plantation of Kerala, India.For Ecol Manage 87: 149-162
Divakara, B.N., Kumar, B.M., Balachandran, P.V. and Kamalam, N.V. (2001). Bamboo hedgerow systems in Kerala, India: Root distribution and competition with trees for phosphorus. Agroforest. Syst., 51: 189-200.

Dindekar, K. (2012). Performance of Wheat crop under Dendrocalamus strictus based AFS in Chhattisgarh. M.Sc. Thesis Dept. of Forestry IGAU, Raipur.

Harne Shailesh Sudhanva (2013). Performance of Paddy crop under Dendrocalamus strictus based AFS in Chhattisgarh. Ph.D. Thesis Dept. of Forestry IGAU, Raipur.

Jiwanlal (2019) Performance of Ginger (Zingiberofficinale Rosc.) under Bamboo (Dendrocalamus strictus (Roxb.) Nees based Agroforestry system in plains of Chhattisgarh. M.Sc. Thesis Dept. of Forestry IGAU, Raipur

Kumar, B.M. (1997). Bamboos in the homegardens of Kerala: A shrinking resource base. J. Nontimber Forest Products, 4: 156-159.

Naugraiya, M.N. and Puri, Sunil. (1997). Bahupyogian Sampada Bans: Utpadan Avam Upyog. Pub. Directorate of Research Services, IGAU, Raipur. pp120.

\section{How to cite this article:}

Rupesh Kumar and Naugraiya, M. N. 2020. Performance of Turmeric (Curcuma longa) under Bamboo (Dendrocalamus strictus) based Agroforestry System in Chhattisgarh. Int.J.Curr.Microbiol.App.Sci. 9(06): 4080-4084. doi: https://doi.org/10.20546/ijcmas.2020.906.477 